\title{
The First Example of Cascade Synthesis of Alkaloid-like Subunit Incorporated into Crown Ethers
}

\author{
Irina G. Ovchinnikova, ${ }^{\circledR 1}$ Olga V. Fedorova, Eugenia G. Matochkina, \\ Mikhail I. Kodess, Andrey A. Tumashov, Pavel A. Slepukhin, Gennady L. Rusinov, \\ and Valery N. Charushin ${ }^{\circledR 2}$
}

I.Y. Postovsky Institute of Organic Synthesis, Ural Branch, Russian Academy of Science, 620041 Ekaterinburg, GSP-147, Russia

${ }^{\circledR 1}$ Corresponding authorE-mail: iov@ios.uran.ru

${ }^{\circledR 2}$ Corresponding author E-mail:charushin@ios.uran.ru

\begin{abstract}
A new type of template-assisted cyclization was found to occur in the course of nucleophilic reactions on chalcone podands, thus resulting in the formation of rather new complex polycyclic compounds. The structure of 25-methyl23,29-diphenyl-8,11,14-trioxa-24-azahexa-cyclo[20.8.0.0 $\left.0^{2,7} \cdot 0^{15,20} \cdot 0^{21,26} \cdot 0^{25,30}\right]$ triaconta-2,4,6,15(20), 16,18,23,28octaene-27-one was established by means of IR (DRA), ${ }^{1} \mathrm{H}$ and ${ }^{13} \mathrm{C} N M R$ spectroscopy, as well as the X-ray crystallography. Polycyclic crownophane with the core of 2-azabicyclo[2.2.2]oct-2-ene can be regarded as synthetic analogues of Daphniphyllum alkaloids.
\end{abstract}

Keywords: Template synthesis, chalcone podands, crown ethers, alkaloids, cascade reactions.

\section{Introduction}

Tandem and cascade reactions were proved to be an important part of synthetic and combinatorial chemistry. ${ }^{[1-3]}$ A vast majority of the syntheses leading to alkaloids, terpenes and other compounds of natural origin appear to be associated with a sequence of several reactions. ${ }^{[4-8]}$ For instance, the synthesis of bicyclic tropinones has been realized as the sequence of two Mannich condensations. ${ }^{[4]}$ Also the synthetic strategy to obtain the family of Daphniphyllum alkaloids, ${ }^{[9]}$ for example the compound 4 , is based on the cascade of reactions, including the Michael nucleophilic addition $^{[7,8]}$ of amide $\mathbf{1}$ to methyl cyclopenten-1-carboxylate $\mathbf{2}$ followed by $\alpha$-alkylation with homogeranyl iodide $\mathbf{3}$ and cyclization of the intermediate $\mathbf{A}$ into dihydropyridine $\mathbf{B}$, bearing both alkenyl and azadiene fragments (Scheme 1).
The intramolecular Diels-Alder cycloaddition is the key step of this synthetic approach affording the core structure of 2-azabicyclo[2.2.2] oct-2-ene in the intermediate $\mathbf{C}$. It is essential, that the alkane bridge connecting both diene and dienophile fragments in the same molecule of the intermediate $\mathbf{B}$ has provided high regio and a stereocontrol of this process. Numerous examples of this approach in total synthesis of polycyclic frameworks are known. ${ }^{[10]}$

In supramolecular chemistry the oligooxyethylene fragment of noncyclic crown ethers in combination with the template effect of metal ions plays a similar role in the synthesis of various macrocycles. ${ }^{[11,12]}$ For instance, recently we have reported ${ }^{[13]}$ on photoinduced [2+2]-cycloaddition of chalcone podands, such as $\mathbf{5}^{[14]}$ (Scheme 2), proceeding in the solutions in the presence of alkaline metal ions and leading directly to the formation of the corresponding

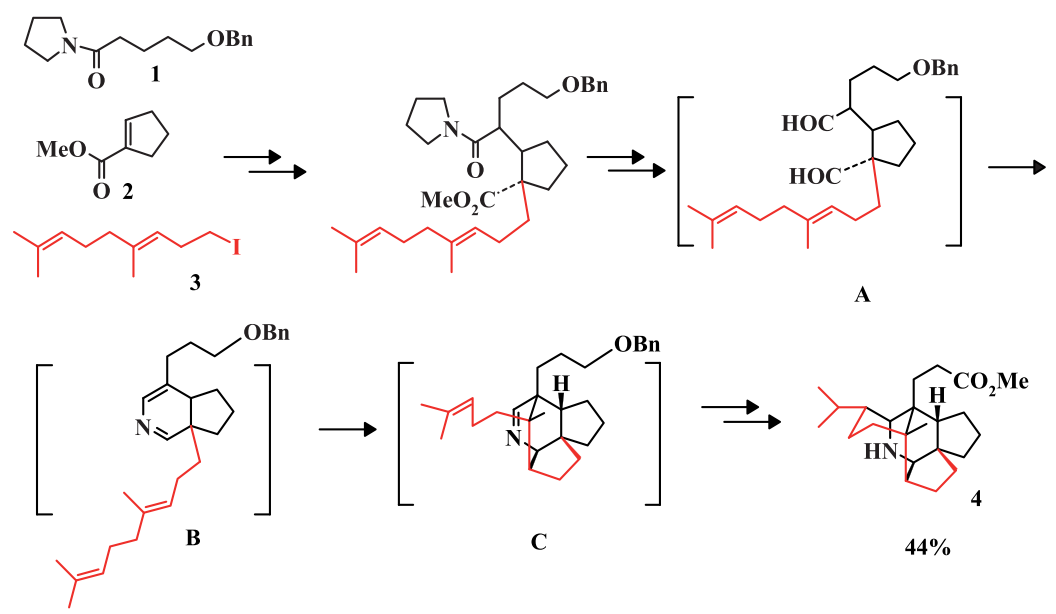

Scheme 1. Synthesis of ( \pm )-methyl homosecondaphniphyllate. 
cyclobutane-containing dibenzo-crown ethers. Furthermore, chalcone podands, in which two enone fragments (Michael acceptors) are linked through conformationally flexible oligooxyethylene chain, may be considered as functionalrich compounds for the synthesis of (hetero)polycyclic structures. However, there are only rare examples of use of podands in the synthesis of heterocyclic compounds directly on the basis of bis(phenoxy)oligo(oxyethylene) fragments, ${ }^{[15]}$ including multicomponent processes. ${ }^{[16]}$

Here we report on the unusual formation of crownophane 7 bearing the azaheterocyclic fragment with the same core structure $\mathbf{C}$ of 2-azabicyclo[2.2.2]oct-2-ene (Scheme 1), as a first example of the cascade of nucleophilic reactions, which take place when chalcone podand $\mathbf{5}^{[11,12]}$ is allowed to react with 4-aminopent-3-en-2-one $\mathbf{6}$ in the presence of alkali ions.

\section{Results and Discussion}

It has been shown that a base-catalyzed and templateassisted cyclization of chalcone podand $\mathbf{5}$ with aminoenone $\mathbf{6}$ affords the polycyclic product 7 which was isolated in a good yield (Scheme 2, Figure 1). The structure of crownophane 7 was established by the X-ray crystallography analysis. The data of HPLC ${ }^{[14]}$ studies have shown that the formation of 7 takes place in the presence of either sodium, potassium or cesium ions to give crownophane 7 in 59,60 and $27 \%$ yields, respectively. Attempts to cause the cyclization of 5 and $\mathbf{6}$ by action of such bases as 1,8-diazabicyclo[5.4.0]undec-7-ene, 2-tert-butyl-1,1,3,3-tetramethyl guanine, triethylamine and tetramethylammonium hydroxide have failed (Table 1).

Table 1. Effect of base on yield of crownophane 7 when chalcone podand 5 was reacted with 4-aminopent-3-en-2-one in DMF according to HPLC.

\begin{tabular}{lcc}
\hline \multirow{2}{*}{ base } & \multicolumn{2}{c}{$\begin{array}{c}\text { Containing of } \mathbf{5} \text { and } \\
\mathbf{7}(\%) \text { in the reaction } \\
\text { mixtures* }\end{array}$} \\
\cline { 2 - 3 } & $\mathbf{5}$ & $\mathbf{7}$ \\
\hline $\mathrm{NaOH}$ & 3 & 59 \\
$\mathrm{KOH}$ & 3 & 60 \\
$\mathrm{Cs}_{2} \mathrm{CO}_{3}$ & 12 & 27 \\
$\mathrm{Et}_{3} \mathrm{~N}$ & 57 & - \\
$\mathrm{Me}_{4} \mathrm{~N}^{+} \mathrm{OH}$ & 68 & - \\
$1,8-$ diazabicyclo[5,4,0]undec-7-ene & 59 & - \\
2-tert-butyl-1,1,3,3-tetramethyl- & 78 & - \\
guanine & & \\
\hline
\end{tabular}

* The use of organic bases results in an increase of the byproduct number from 3 (in case alkali bases) to $9-11$ compounds (with concentrations $2-7 \%)$.

Also, it has been found that the template-assisted cyclization of chalcone podand $\mathbf{5}$ with urea $\mathbf{6}$ results in the formation of crownophane 8 in $64 \%$ yield (Scheme 3, Figure 2).

According to the X-ray crystallography data, the skeleton of 14-membered crown ether fragment in compound 7 (Figure 1) is practically identical with that of crownophane 8 (Figure 2). The polyether chain $\mathrm{C}(1)-\mathrm{O}(1)-$ $\mathrm{C}(39)-\mathrm{C}(38)-\mathrm{O}(2)-\mathrm{C}(37)-\mathrm{C}(36)-\mathrm{O}(3)-\mathrm{C}(35)$ has the $a-g^{(+)}-a-$ $a-g^{(-)}-a$ conformation (torsion angles $\mathrm{O}(3) \mathrm{C}(36) \mathrm{C}(37) \mathrm{O}(2)$ and $\mathrm{O}(2) \mathrm{C}(38) \mathrm{C}(39) \mathrm{O}(1)$ are equal to $63.38(1)^{\circ}$ and $65.95(1)^{\circ}$,

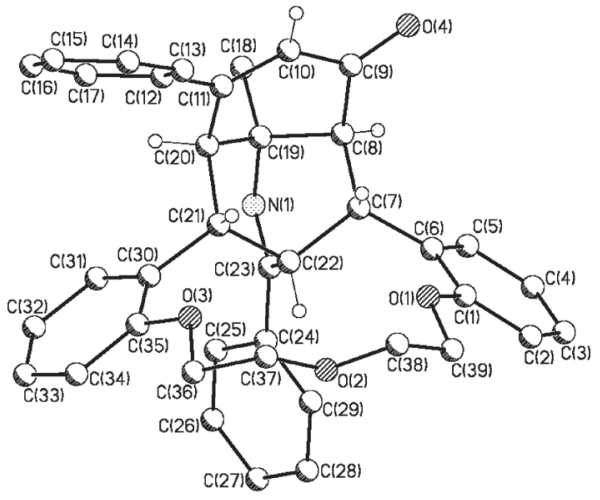

Figure 1. Molecular structure of 7 (numbering of atoms is given according to the X-ray analysis data, majority of hydrogen atoms are omitted).

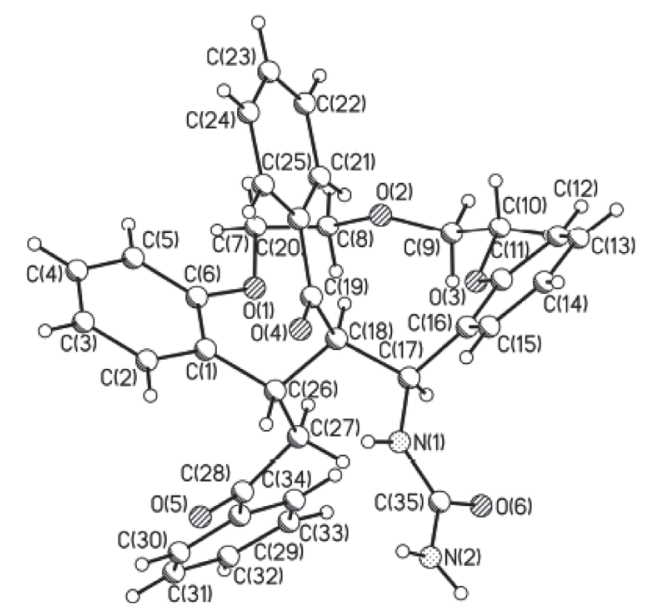

Figure 2. X-Ray crystallography structure of $\mathbf{8}$ (numbering of atoms comes from X-ray analysis).

respectively), forming a similar bowl structure with atoms $\mathrm{C}(7), \mathrm{C}(21), \mathrm{C}(37)$ and $\mathrm{C}(38)$ in the basis (deviations of atoms from a root-mean-square plane are in the frames of $0.007 \AA$ ). Six-membered rings of 2-azabicyclo[2.2.2] oct-2-ene are stabilized in a boat-conformation (values of their torsion angles vary within the range of 48.61(2) $\left.59.37(2)^{\circ}\right)$ with pseudoequatorial phenoxy substituents at $C(7)$ and $C(21)$ carbon atoms in the $C(21)-C(7)-C(8)$ $\mathrm{C}(19)-\mathrm{C}(20)-\mathrm{C}(21)$ six-membered ring (torsion angles are in the range $\left.175.43-117.42(2)^{\circ}\right)$, while the cyclohexenone fragment has a more planar twist-conformation. Distances from $C(8)$ and $C(19)$ to the root-mean-square plane, which passes through $\mathrm{C}(10), \mathrm{C}(11), \mathrm{C}(20)$ and $\mathrm{C}(9)$, are $0.265(1)$ and 0.531(1) $\AA$, respectively. Compound 7 (racemate) contains six asymmetric centers $\mathrm{C}(8), \mathrm{C}(7), \mathrm{C}(22), \mathrm{C}(21), \mathrm{C}(20)$ and $\mathrm{C}(19)$ with a rac- $\left(8 S^{*}, 7 R^{*}, 22 R^{*}, 21 R^{*}, 20 S^{*}, 19 S^{*}\right)$ configuration. This crown ether, bearing the core structure of 2-azabicyclo[2.2.2]oct-2-ene, can be regarded as a synthetic analogue of Daphnezomine $N$ alkaloid (Scheme 1, C), ${ }^{[9]}$ isolated from the stems of Daphniphyllum humile.

Analysis of the ${ }^{1} \mathrm{H}$ and ${ }^{13} \mathrm{C}$ NMR spectra recorded for compound 7, including two-dimension ${ }^{1} \mathrm{H}-{ }^{1} \mathrm{H}$ COSY, ${ }^{1} \mathrm{H}-{ }^{13} \mathrm{C}$ HSQC and HMBC experiments, has shown that resonance signals for protons at $\mathrm{C}_{26}\left(\delta 2.67 \mathrm{ppm}, \mathrm{dd}, J_{26,21}=5.1, J_{26,30}=1.4\right.$ $\mathrm{Hz})$ and $\mathrm{C}_{30}\left(\delta 3.25 \mathrm{ppm}, \mathrm{dd}, J_{30,1}=4.0, J_{30,26}=1.4 \mathrm{~Hz}\right)$ of 2 -azabicyclo[2.2.2] oct-2-ene fragment are registered in a relatively 
Crownophane with Alkaloid-like Core
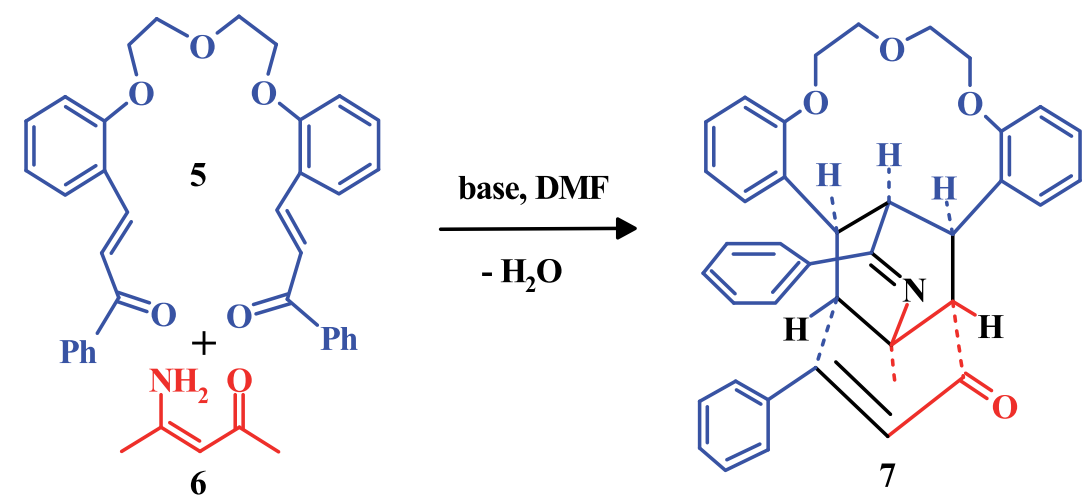

Scheme 2. Synthesis of crownophane 7.

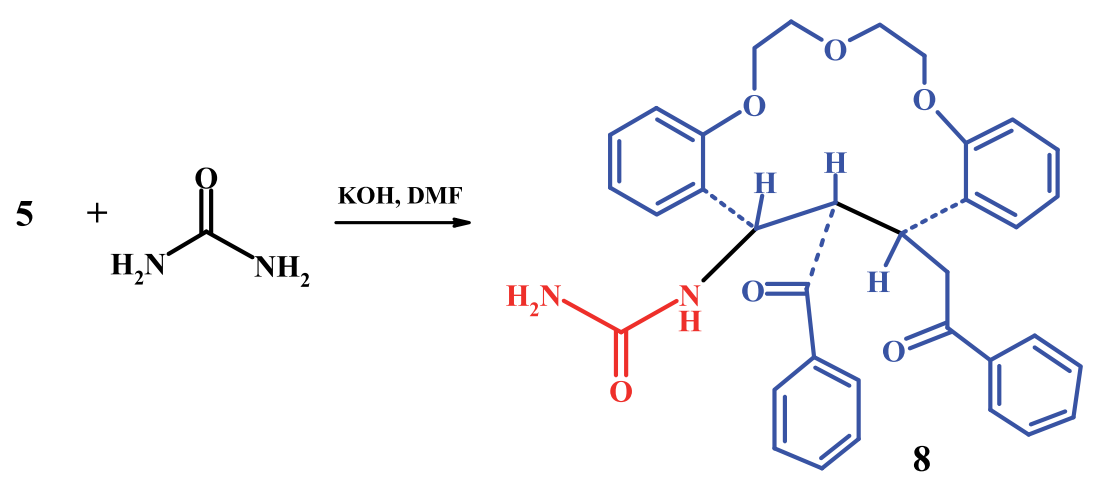

Scheme 3. Synthesis of crownophane 8.

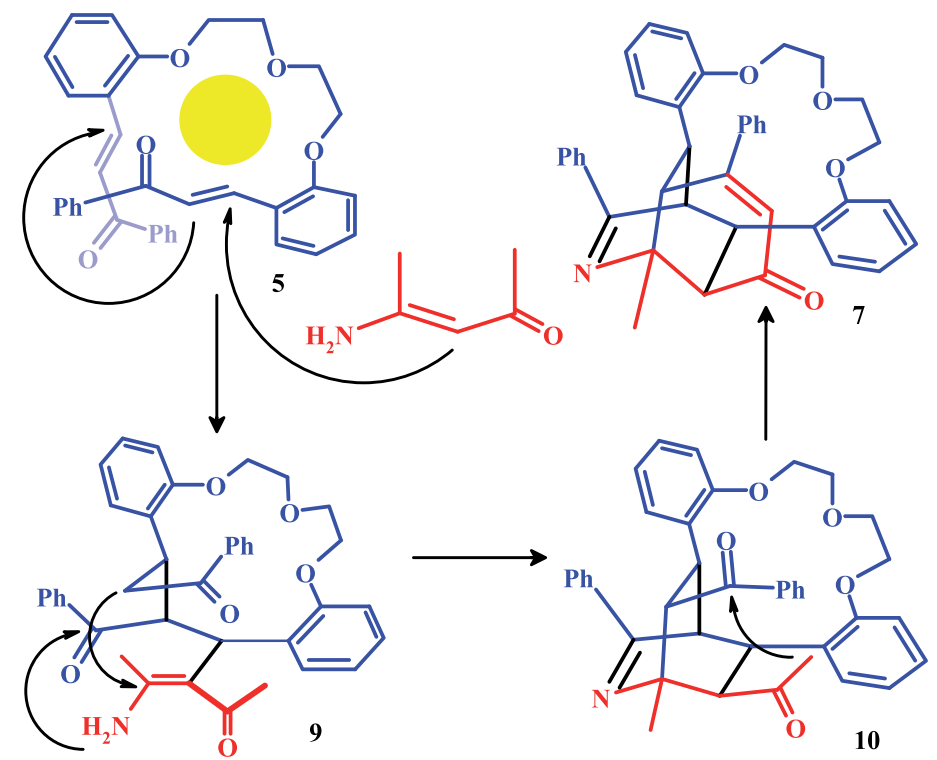

Scheme 4. A plausible cascade $A_{N}-A_{N}-A_{N}$ mechanism.
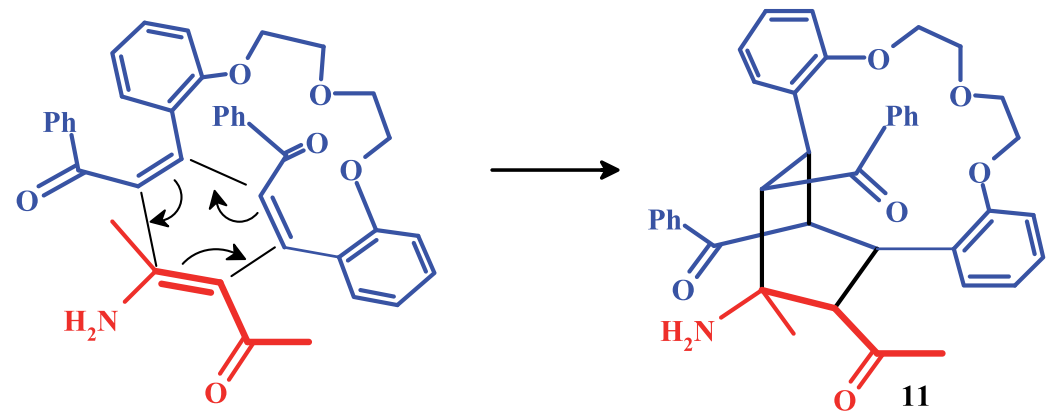

Scheme 5. An alternative $[2+2+2]$ cycloaddition mechanism. 
high field, whereas signals of three other protons at $\mathrm{C}_{1}, \mathrm{C}_{22}$ and $\mathrm{C}_{21}$ undergo a downfield shift and resonate at $\delta 3.66-3.86 \mathrm{ppm}$ due to electronegative through-space effects of oxygen atoms of the polyether chain. This phenomenon has been proved by the X-ray crystallography data, showing a number of shortened $\mathrm{C}(7)-\mathrm{H} \cdots \mathrm{O}(1), \mathrm{C}(21)-\mathrm{H} \cdots \mathrm{O}(3), \mathrm{C}(22)-\mathrm{H} \cdots \mathrm{O}(1)$ and $\mathrm{C}(22)-\mathrm{H} \cdots \mathrm{O}(3)$ intramolecular contacts, which are equal to 2.247 (1), 2.325 (1), 2.773 (2) and 3.052 (2) Å, respectively (Figure 1).

One of possible ways for the formation of polycyclic crownophane 7 (Scheme 4) suggests that the reaction is initiated by the Michael $\mathrm{C}$-addition of enamine $\mathbf{6}$ to the $\mathrm{C}=\mathrm{C}$ double bond of chalcone podand $\mathbf{5}$. The formation of 7 takes place in the presence of sodium, potassium or cesium hydroxides, thus suggesting that the template assistance of these ions ${ }^{[11-13]}$ might be a driving force to push a domino sequence of intramolecular transformations. It is well-known that the conformationally mobile podands are able to manifest various types of complexes with alkali ions. In our case, they form, most likely, complexes of the "roost" or "butterfly-like" type, where the guest is arranged at the top of the binding (oxyethylene fragment) surface of the host (see ref. ${ }^{[12]} \mathrm{Ch} .4$, pp. 287-288 and ${ }^{[17]}$ ). A similar effect has been observed earlier in photoinduced transformation of chalcone podands. ${ }^{[13]}$ Thus, the secondary $\mathrm{C}$-addition results in the formation of the cyclic ether 9. Orientation of the $\mathrm{C}=\mathrm{O}$ groups in the intermediate 9 provides their vicinity to $\mathrm{N}$ - and $\mathrm{C}$-nucleophilic centers, thus facilitating subsequent intramolecular condensations, leading to $\mathbf{1 0}$, and finally to the compound 7 .

The structure of crown ether $\mathbf{8}$ derived from the reaction of chalcone podand $\mathbf{5}$ with urea is also an argument in favor of this cascade $A_{N}-A_{N}-A_{N}$ mechanism, involving a sequence of inter- and intramolecular nucleophilic additions. A genetic link between crownophanes $\mathbf{7}$ and $\mathbf{8}$ is evidenced by comparison of their X-ray crystallography data. In particular, the oxygen $\mathrm{O}(2)$ is orientated at the benzene ring of phenacyl substituent at $\mathrm{C}(18)$ of $\mathbf{8}$ and at $\mathrm{C}(23)$ of 7 , the $\mathrm{C}(21)-\mathrm{H} \cdots \mathrm{O}(2)$ distance is equal to 2.571 (1) and $\mathrm{C}(29)-\mathrm{H} \cdots \mathrm{O}(2)$ to $4.747(1)$ $\AA$, respectively (Figures 1, 2). Furthermore, the angle between the root-mean-square planes, which pass through $\mathrm{C}(35), \mathrm{C}(33), \mathrm{C}(32), \mathrm{C}(30)$ and $\mathrm{C}(6), \mathrm{C}(1), \mathrm{C}(3), \mathrm{C}(4)$ atoms of aryl substituents in 7 , is equal to $112.32(2)^{\circ}$ and, practically, coincides with that for crownophane 8 (the angle between root-mean-square planes $\mathrm{C}(13), \mathrm{C}(14), \mathrm{C}(11), \mathrm{C}(16)$ and $\mathrm{C}(6)$, $\mathrm{C}(5), \mathrm{C}(2), \mathrm{C}(3)$ is equal to $\left.112.8(2)^{\circ}\right)$.

An alternative $[2+2+2]$ cycloaddition mechanism for the formation of crownophane $\mathbf{1 1}$ from starting chalcone podand $\mathbf{5}$ and enamine $\mathbf{6}$ can be advanced (Scheme 5). This pericyclic reaction is allowed thermally, while the reaction requirements to have three $\mathrm{C}=\mathrm{C}$ bonds in close vicinity to each other and to get these bonds to be located in one plane to facilitate the formation of an aromatic $6 \pi$-electron transition state can possibly be attributed to the templateeffect of alkali metal ions.

Subsequent two cyclizations on the carbonyl groups afford the crownophane 7 .

\section{Conclusions}

A new type of template-assisted cyclization has been found to occur in the reaction of chalcone podand $\mathbf{5}$ with enamine $\mathbf{6}$ in the presence of alkali metal ions, and two plausible mechanisms for the formation of alkaloid-like crownophane 7 , including the cascade $A_{N}-A_{N}-A_{N}$ sequence or the $[2+2+2]$ pericyclic reaction between two $\mathrm{C}=\mathrm{C}$ bonds of 5 and enamine $\mathbf{6}$ have been advanced. A high stereoselectivity of the process is provided by the template effect of alkali metal ions on orientation of the reactive groups, in addition to the effect of oligooxyethylene fragment of chalcone podand. ${ }^{[15,16]}$ Stereochemical features are also in good agreement with the pericyclic character of the reaction, proceeding through the formation of an aromatic $6 \pi$-electron transition state promoted by alkali metal ions, available in the reaction mixture.

\section{Experimental}

4-Aminopent-3-en-2-one was preliminary obtained from pentane-2,4-dione and ammonium hydroxide at heating on a glyceric bath. All other reagents were of commercial quality. Solvents were dried and purified by standard methods. Routine monitoring of reaction mixtures was carried out using Sorbfil UV 254 (Russia). Column chromatography was done on Davisil silica gel LC $60 \mathrm{~A}(40-63 \mu \mathrm{m})$. MS data were obtained using quadrupole Shimadzu LCMS-2010 system in positive mode with an APCI probe installed with $\mathrm{MeOH}$ or $\mathrm{CH}_{3} \mathrm{CN}$ as the solvent. ${ }^{1} \mathrm{H}$ NMR and ${ }^{13} \mathrm{C}$ NMR spectra were run on a "Bruker DRX-400" (at 400 and $100 \mathrm{MHz}$, respectively, with $J$ values in $\mathrm{Hz})$ using TMS and DMSO- $d_{6}\left(\delta_{C} 39.5 \mathrm{ppm}\right)$ as references. IR spectra were run on «PerkinElmer» (Spectrum One) spectrometer.

General Method. The following procedure for the synthesis of 7 and 8 has been used: a solution of $0.25 \mathrm{~g}(0.48 \mathrm{mmol})$ of chalcone podand $\mathbf{5},{ }^{[13,14]} 0.095 \mathrm{~g}(0.96 \mathrm{mmol})$ of 4-aminopent-3en-2-one and $0.054 \mathrm{~g}(0.96 \mathrm{mmol})$ of $\mathrm{KOH}$ (or $\mathrm{NaOH}, \mathrm{Cs}_{2} \mathrm{CO}_{3}$, 1,8-diazabicyclo[5.4.0]undec-7-ene, 2-tert-butyl-1,1,3,3-tetramethylguanine, triethylamine and tetramethylammonium hydroxide) in DMF $(10 \mathrm{ml})$ was heated up to $80{ }^{\circ} \mathrm{C}$, and kept at this temperature for $35 \mathrm{~h}$. The reaction mixture was evaporated and a residue obtained was washed out with several portions of water on a filter. The subsequent chromatography of dry residue on a column with silica gel (TLC, benzene/ethyl acetate $1: 1, R_{f}=0.63$ ) yielded $0.13 \mathrm{~g}$ (48\%, 60\% according to HPLC) 7 as colorless crystals. Compound $\mathbf{8}$ was obtained analogously by interaction of $0.25 \mathrm{~g}(0.48 \mathrm{mmol})$ of chalcone podand 5 with $0.058 \mathrm{~g}$ $(0.96 \mathrm{mmol})$ of urea. The dry residue was subjected to chromatography on a silica gel column (TLC, hexane/ethyl acetate $1: 1$; ethyl acetate, $\left.R_{f}=0.38\right)$ to yield $0.17 \mathrm{~g}(64 \%)$. The content of 7 in the reaction mixtures was analyzed by analytical RP-HPLC (a Phenomenex Luna C-18(2) $(4.6 \times 250 \mathrm{~mm}, 5 \mu \mathrm{m})$ column) and by using a tuneable UV detector set at $280 \mathrm{~nm}$. A solution of $\mathrm{CH}_{3} \mathrm{CN}$ was changed from 40 to $90 \%$ by $0.1 \% \mathrm{Et}_{3} \mathrm{~N}$ in $\mathrm{H}_{2} \mathrm{O}(\mathrm{pH} 9.3)$ ) with a flow rate of $0.8 \mathrm{ml} / \mathrm{min}$ in gradient mode, $t_{\mathrm{R}}=22.3 \mathrm{~min}$ (compound 7), $t_{\mathrm{R}}=26.3 \mathrm{~min}$ (compound 5).

25-Methyl-23,29-diphenyl-8,11,14-trioxa-24azahexacyclo $\left[20 \cdot 8 \cdot 0 \cdot 0^{2,7} \cdot 0^{15,20} \cdot 0^{21,26} \cdot 0^{25,30}\right]$ triaconta2,4,6,15(20),16,18,23,28-octaene-27-one, 7. m.p. $280-282^{\circ} \mathrm{C}$. Found: C 80.53, N 2.42, H $5.76 \%$. $\mathrm{C}_{39} \mathrm{H}_{35} \mathrm{NO}_{4}$ requires C 80.55, $\mathrm{N} 2.41, \mathrm{H}$ 6.02. $\mathrm{m} / \mathrm{z}$ (ESI-MS) (\%) $582.5(100)\left[(\mathrm{M}+\mathrm{H})^{+}\right] .{ }^{1} \mathrm{H}$ NMR $\left(400 \mathrm{MHz}, \mathrm{DMSO}-d_{6}, J / \mathrm{Hz}\right) \delta_{\mathrm{H}}$ ppm: $1.85\left(3 \mathrm{H}, \mathrm{s}, \mathrm{CH}_{3}\right), 2.67(1 \mathrm{H}$, $\mathrm{H}(26), \mathrm{dd}, J=5.1,1.4), 3.25(1 \mathrm{H}, \mathrm{H}(30), \mathrm{dd}, J=4.0,1.4), 3.66$ $(1 \mathrm{H}, \mathrm{H}(22), \mathrm{t}, J=2.3), 3.71-3.90$ (6H, H(1), H(21), m, O- $\left.\mathrm{CH}_{2}\right)$, $3.94,4.05,4.14,4.21\left(1 \mathrm{H}, \mathrm{m}, \mathrm{O}-\mathrm{CH}_{2}\right), 6.44(1 \mathrm{H}, \mathrm{H}(28), \mathrm{s}), 6.60-$ 6.69 (2H. H(4), H(18), m), $6.81-6.89$ (5H, H(6), H(16), H(17), H(2"), m), 6.97 - 7.09 (5H, H(3), H(5). H(19), H(3"), m), 7.11 (1H, $\left.\mathrm{H}\left(4^{\prime \prime}\right), \mathrm{tm}, J=7.4\right), 7.28$ (2H, H(3'), tm, $\left.J=7.4\right), 7.37$ (1H, H(4'), $\mathrm{tm}, J=7.4), 7.53\left(2 \mathrm{H}, \mathrm{H}\left(2^{\prime}\right), \mathrm{m}\right) .{ }^{13} \mathrm{C}$ NMR $\left(100 \mathrm{MHz}, \mathrm{DMSO}-d_{6}\right)$ $\delta_{\mathrm{C}}$ ppm: $25.57\left(\mathrm{CH}_{3}\right), 39.21(\mathrm{C}(21)), 42.70(\mathrm{C}(30)), 43.97(\mathrm{C}(1))$, 
$46.29(\mathrm{C}(22)), 51.97(\mathrm{C}(26)), 61.87(\mathrm{C}(25)), 67.01,67.14,68.74$, 68.83 (C(9) - C(13)); 111.02, 111.08 (C(6), C(16)); 118.73 (C(28)); 119.80, 120.06 (C(4), C(18)); 125.19 (C(2”)); 126.70 (C(2')); 126.96 (C(5), C(17)); 127.65 (C(3”)); 127.70, 127.74 (C(3), C(19)); 128.85 $\left(\mathrm{C}\left(3^{\prime}\right)\right) ; 129.48$ (C(4”)); 129.79, 129.87 (C(2), C(20)); 130.50 $\left(\mathrm{C}\left(4^{\prime}\right)\right)$; 136.89 (C(1")); 138.26 (C(1')); 155.82, 155.92 (C(7), $\mathrm{C}(15)) ; 163.73$ (C(23)); 176.21 (C(29)); 200.59 (C(27)). IR (DRA) $v \mathrm{~cm}^{-1}:$ 693, 749, 766 (arom.); 851, 874, 930, 944, 1030; $1060\left(v_{\mathrm{s},}\right.$ $\left.\mathrm{C}_{\text {arom }}-\mathrm{O}-\mathrm{C}_{\text {alk }}\right) ; 1097,1113,1141\left(v_{\text {as }}, v_{\mathrm{s},} \mathrm{C}_{\text {alk }}-\mathrm{O}\right) ; 1254\left(\mathrm{v}_{\text {as, }} \mathrm{C}_{\text {arom }}-\mathrm{O}-\right.$ $\left.\mathrm{C}_{\text {alk }}\right) ; 1276,1294,1348,1371,1451,1490 ; 1571,1601(\delta, \mathrm{C}=\mathrm{C}$, $\mathrm{C}=\mathrm{N}) ; 1659(\delta, \mathrm{C}=\mathrm{O}) ; 2826,2873,2929,2946,2967\left(\delta, \mathrm{C}_{\mathrm{alk}}-\mathrm{H}\right)$; $3032,3062\left(\delta, \mathrm{C}_{\text {arom }}-\mathrm{H}\right)$.

1-(17-phenacyl-18-(2-oxo-2-phenylethyl)-7,9,10,16,17,18hexahydro- $6 H$-dibenzo[h, $m][1,4,7]$ trioxacyclotetradec-16-yl) urea, 8. m.p. $241-243^{\circ} \mathrm{C}$. Found: C $72.46, \mathrm{~N} 4.72$, H $5.82 \%$. $\mathrm{C}_{35} \mathrm{H}_{34} \mathrm{~N}_{2} \mathrm{O}_{6}$ requires $\mathrm{C} 72.66, \mathrm{~N} 4.84, \mathrm{H}$ 5.88. $\mathrm{m} / z$ (ESI-MS) (\%) $579.6(100)\left[(\mathrm{M}+\mathrm{H})^{+}\right] .{ }^{1} \mathrm{H}$ NMR $\left(400 \mathrm{MHz}, \mathrm{DMSO}-\mathrm{d}_{6}, J / \mathrm{Hz}\right) \delta_{\mathrm{H}}$ ppm: 3.57 (1H, H(18'b), dd, $J=15.0,3.7), 3.77-3.87$ (2H, H(18), $\left.\mathrm{m}, \mathrm{OCH}_{2}\right), 4.0-4.18\left(7 \mathrm{H}, \mathrm{H}(18 \mathrm{a}), \mathrm{m}, \mathrm{OCH}_{2}\right), 4.27\left(1 \mathrm{H}, \mathrm{OCH}_{2}\right.$, $\mathrm{dm}, J=9.8), 5.64-5.75(2 \mathrm{H}, \mathrm{H}(17), \mathrm{H}(16) \mathrm{m}), 6.15\left(2 \mathrm{H}, \mathrm{NH}_{2}, \mathrm{~s}\right)$, $6.42-6.47$ (2H, H(2), H(4), m), $6.56(1 \mathrm{H}, \mathrm{H}(1), \mathrm{dd}, J=7.7,1.9)$, $6.61-6.68$ (2H, H(12), H(14), m), 6.77 (1H, H(3), ddd, $J=7.9,7.7$, 1.9), $6.87-7.03$ (5H, H(13), H(15), H(3'), NH, m), 7.21 (1H, H(4'), tm, $J=7.4), 7.43$ (2H, H(2'), m); 7.50 (2H, H(3”), tm, $J=7.5) ; 7.61$ (1H, H(4"), tm, $J=7.4), 7.82$ (2H, H(2"), m). ${ }^{13} \mathrm{C}$ NMR (100 MHz, DMSO-d $\left.{ }_{6}\right) \delta_{\mathrm{C}}$ ppm: $38.19\left(\mathrm{C}\left(18^{\prime}\right)\right)$; $43.82(\mathrm{C}(18))$; 45.75 (C(17)); 47.28 (C(16)); 66.23, 67.06, 69.65, 69.77 (C(6) - C(10)); 110.03 (C(12)); $110.44(\mathrm{C}(4)) ; 119.35(\mathrm{C}(2)) ; 119.64(\mathrm{C}(14)) ; 126.37$ (C(15)); 126.97 (C(18a)); 127.39 (C(3’)); 127.46 (C(2’)); 127.57 (C(13)); 127.74 (C(2”)); 127.79 (C(3)); 128.70 (C(3”)); 129.53 (C(15a)); 132.09 (C(1)); 132.42 (C(4')); 132.80 (C(4”)); 137.06 (C(1”)); 137.67 $\left(\mathrm{C}\left(1^{\prime}\right)\right) ; 154.92$ (C(11a)); $156.81(\mathrm{C}(4 \mathrm{a})) ; 158.32\left(\mathrm{C}\left(16^{\prime}\right)=\mathrm{O}\right) ; 199.55$ $\left(\mathrm{C}\left(18^{\prime \prime}\right)=\mathrm{O}\right) ; 205.25\left(\mathrm{C}\left(17^{\prime}\right)=\mathrm{O}\right)$. IR (DRA) $v \mathrm{~cm}^{-1}: 688,718,744$, 756 (arom.); 856, 934, 949, 1000; $1061\left(v_{\mathrm{s},} \mathrm{C}_{\text {arom }}-\mathrm{O}-\mathrm{C}_{\mathrm{alk}}\right) ; 1104,1118$, $1141\left(v_{\mathrm{as}}, v_{\mathrm{s},} \mathrm{C}_{\mathrm{alk}}-\mathrm{O}\right) ; 1252\left(\mathrm{v}_{\mathrm{as}}, \mathrm{C}_{\text {arom }}-\mathrm{O}-\mathrm{C}_{\mathrm{alk}}\right) ; 1282,1351,1372,1448$, 1493,$1513 ; 1599(\delta, \mathrm{C}=\mathrm{C}, \mathrm{C}=\mathrm{N}) ; 1662,1673,1683(\delta, \mathrm{C}=\mathrm{O}) ; 2823$, 2867, 2890, $2925\left(\delta, \mathrm{C}_{\mathrm{alk}}-\mathrm{H}\right) ; 3067\left(\delta, \mathrm{C}_{\text {arom }}-\mathrm{H}\right) ; 3362,3400,3474$ $\left(-\mathrm{NH}_{2},-\mathrm{NH}-\right)$.

X-Ray crystallography. Crystals of $\mathbf{7}$ and $\mathbf{8}$ were obtained by the slow evaporation of DMF solutions. Single crystals of these compounds were mounted on a "Xcalibur 3"-CCD diffractometer (graphite monochromatized Mo-K $\alpha$ radiation, $\lambda=0.71073 \AA$, $\omega$ scan mode, $T=295 \mathrm{~K}$ ). The structure was solved by the direct methods with the set of programs SHELX97 and refined with anisotropic thermal parameters. ${ }^{[18]}$ All hydrogen atoms were located in difference Fourier synthesis, but for the further refinement their geometrically calculated positions were used. All hydrogen atoms were refined with an isotropic approximation. 7: $\mathrm{C}_{39} \mathrm{H}_{35} \mathrm{NO}_{4}$, triclinic, space group $P-1, a=9.9836(14) \AA$, $b=11.2901(4) \AA, c=16.680(2) \AA, \alpha=73.598(11)^{\circ}, \beta=74.857(11)^{\circ}$, $\gamma=81.557(11)^{\circ}, V=1543.4(3) \AA^{3} ; Z=2, \mu=0.080 \mathrm{~cm}^{-1}, \rho=1.252$ $\mathrm{g} \mathrm{cm}^{-3} ; 20464$ reflections measured $\left(2.70<\theta<28.28^{\circ}\right), 7473$ unique reflections $[R(\mathrm{int})=0.0140], R_{1}=0.0361, w R_{2}=0.0425$ for 3189 reflections with $I>2 \sigma(I), R_{1}=0.1218, w R_{2}=0.0459$ for all reflections. 8 (solvate): $\mathrm{C}_{35} \mathrm{H}_{34} \mathrm{~N}_{2} \mathrm{O}_{6} \cdot \mathrm{C}_{3} \mathrm{H}_{7} \mathrm{ON}$, triclinic, space group $P-1, a=10.3728(11) \AA, b=10.6608(7) \AA, c=16.3538(12) \AA$, $\alpha=90.665(6)^{\circ}, \beta=92.301(7)^{\circ}, \gamma=97.821(7)^{\circ}, V=1789.9(3) \AA^{3}$; $Z=2, \mu=0.084 \mathrm{~cm}^{-1}, \rho=1.209 \mathrm{~g} \mathrm{~cm}^{-3} ; 20630$ reflections measured $\left(2.84<\theta<32.41^{\circ}\right), 10509$ unique reflections $[R($ int $)=0.0269]$, $R_{1}=0.0409, w R_{2}=0.0729$ for 3794 reflections with $I>2 \sigma(I)$, $R_{1}=0.1455, w R_{2}=0.0798$ for all reflections. The atomic coordinates and other X-Ray crystallographic experimental data for the structure of $\mathbf{7}$ and $\mathbf{8}$ have been deposited with the Cambridge Crystallographic Data Centre (CCDC 795212 7, CCDC 795213 8). Copies of the data can be obtained free of charge on application to The Director, CCDC, 12 Union Road, Cambridge CB2 1EZ, UK [fax: (internat.)+44-1223/336-033; e-mail: deposit@ccdc.cam. ac.uk].
Acknowledgements. This research has been carried out with the financial support of the Presidium of Ural Branch of the Russian Academy of Science (the projects «Design of supramolecular structures containing heterocyclic fragments, № 09-T-3-1024» and «Scientific basics for development of pharmaceuticals of both natural and synthetic origin, № 09-И-3-2004»).

\section{References}

1. Litvinov V.P. Russ. Chem. Rev. 2003, 72 (1), $69-85$.

2. a) Bienayme H., Hulme C., Oddon G., Schmitt P. Chem. Eur. J. 2000, 6(18), 3321 - 3329; b) Nefzi A., Ostresh J.M., Houghten R.A. Chem. Rev. 1997, 97, 449 - 472.

3. a) Kappe C.O. Acc. Chem. Rec. 2000, 33, 879 - 888; b) Evdokimov N.M., Kireev A.S., Yakovenko A.A., Antipin M.Y., Magedov I.V., Kornienko A. J. Org. Chem. 2007, 72, 3443 - 3457; c) Smith C.D., Gavrilyuk J.I., Lough A.J., Batey R.A. J. Org. Chem. 2010, 75, $702-715$; d) Jiang B., Li C., Shi F., Tu S., Kaur P., Wever W., Li G. J. Org. Chem. 2010, 75, $2962-2965$.

4. Tietze L.F. Chem. Rev. 1996, 96, 115 - 136.

5. Parsons P.J., Penkett C.S., Shell A.J. Chem. Rev. 1996, 96, $195-206$.

6. Gaich T., Baran P.S. J. Org. Chem. 2010, 75, 4657 - 4673.

7. a) Burke S.D., Murtiashaw C.W., Saunders J.O., Oplinger J.A., Dike M.S. J. Am. Chem. Soc. 1984, 106, 4558 - 4566; b) Danishefsky S., Vaughan K., Gadwood R., Tsuzuki K. J. Am. Chem. Soc. 1981, 103, 4136 - 4141; c) Bornack W. K., Bhagwat S.S., Ponton J., Helquist P. J. Am. Chem. Soc. 1981, 103, $4647-4648$.

8. a) Suzuki M., Yanagisawa A., Noyori R. J. Am. Chem. Soc. 1988, 110, 4718 - 4726; b) Johnson C.R., Penning T.D. J. Am. Chem. Soc. 1988, 110, 4726 - 4735; c) Lipshutz B.H., Wood M.R. J. Am. Chem. Soc. 1994, 116, 11689 - 11702.

9. a) Ruggeri R.B., Hansen M.M., Heathcock C.H. J. Am. Chem. Soc. 1988, 110, 8734 - 8736; b) Wallace G.A., Heathcock C.H. J. Org. Chem. 2001, 66, 450 - 454; c) Bitar H.E., Nguyen V.H., Gramain A., Sévenet T., Bodo B. Tetrahedron Lett. 2004, 45, 515 - 518; d) Kobayashi J., Kubota T. Nat. Prod. Rep. 2009, 26, $936-962$.

10. a) Martin S.F., Desai S.R., Phillips G.W., Miller A.C. J. Am. Chem. Soc. 1980, 102, 3294 - 3296; b) Funk R.L., Vollhardt K.P.C. J. Am. Chem. Soc. 1980, 102, 5253 - 5261; c) Stork G., Chan T.Y. J. Am. Chem. Soc. 1995, 117, 6595 - 6596; d) Shing T.K.M., Yang J. J. Org. Chem. 1995, 60, 5785 - 5789; e) Roush W.R., Koyama K., Curtin M.L., Moriarty K.J. J. Am. Chem. Soc. 1996, 118, 7502 - 7512; f) Winkler J.D., Kim H.S., Kim S., Ando K., Houk K.N. J. Org. Chem. 1997, 62, 2957 - 2962; g) Batey R.A., Thadani A.N., Lough A.J. J. Am. Chem. Soc. 1999, 121, $450-451$; h) Toró A., Nowak P., Deslongchamps P. J. Am. Chem. Soc. 2000, 122, $4526-$ 4527; i) Waizumi N., Itoh T., Fukuyama T. J. Am. Chem. Soc. 2000, 122, 7825 - 7826; j) Wada E., Kumaran G., Kanemasa S. Tetrahedron Lett. 2000, 41, 73 - 76.

11. a) Host Guest Complex Chemistry Macrocycles. Synthesis, Structures, Applications (F. Vögtle, E. Weber, Eds) SpringerVerlag, Berlin, 1985; b) Gokel G.W. Crown Ethers and Cryptands (Monographs in Supramolecular Chemistry) The Royal Society of Chemistry: Cambridge, 1991, 3, 190; c) Fenlon E.E. Eur. J. Org. Chem. 2008, 5023 - 5035.

12. Weber E., Toner J.L., Goldberg I., Vögtle F., Laidler D.A., Stoddart J.F., Bartsch R.A., Liotta C.L. Crown Ethers and Analogs John Wiley \& Sons: Chichester, 1989, 558.

13. Ovchinnikova I.G., Fedorova O.V., Matochkina E.G., Kodess M.I., Slepukhin P.A., Rusinov G.L. Russ. Chem. Bull., Int. Ed. 2009, 58(6), 1180 - 1191. 
14. Ovchinnikova I.G., Fedorova O.V., Slepukhin P.A., Litvinov I.A., Rusinov G.L. Crystallogr. Rep. 2009, 54(1), $31-39$.

15. a) Arrowsmith J., Jennings Sh.A., LangnelD.A.F., Wheelhouse R.T., Stevens M.F.G. J. Chem. Soc. Perkin Trans. 1 2000, 24, 4432 - 4438; b) Molina P., Tarraga A., Diaz I., Espinosa A., Gaspar C. Heterocycles 1993, 36, 1263 - 1278; c) Katritzky A.R., Belyakov S.A., Denisko O.V., Maran U., Dalal N.S. J. Chem. Soc., Perkin Trans. 2 1998, N. 3, 611 - 616; d) Yildiz M., Kilic Z., Hokelek T. J. Molecular Structure 1999, 510, $227-235$.
16. a) Van Bergen T.J., Kellogg R.M. J. Chem. Soc., Chem. Commun. 1976, 964 - 965; b) Zhidovinova M.S., Fedorova O.V., Rusinov G.L., Ovchinnikova I.G. Molecular Diversity 2003, 6, 323 - 326; c) Levov A.N., Le Tuan Anh, Komarova A.I., Strokina V.M., Soldatenkov A.T., Khrustalev V.N. Russ. J. Org. Chem. 2008, 44(3), 456-461; d) Le Tuan Anh, Levov A.N., Soldatenkov A.T., Gruzdev P.D., Chyong Khong Khieu Russ. J. Org. Chem. 2008, 44(3), $462-464$.

17. Cram D.J. Angew. Chem., Int. Ed. Engl. 1986, 25, 1039 - 1057.

18. Sheldrick G.M. Acta Crystallogr., Sect. A: Found. Crystallogr. 2008, 64, 112 . 